\title{
球状アルミナ担体中でのニッケル微粒子の分布制御
}

\author{
藤山 毅・大塚 正志・上野 晃史

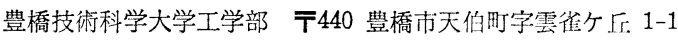

(1987 年 4 月 13 日＼cjkstart受理)

\begin{abstract}
Impregnation Profile of Ni Fine Particles in $\mathrm{Ni} / \mathrm{SiO}_{2} / \mathrm{Al}_{2} \mathrm{O}_{3}$ Catalyst
Takeshi FUJIYAMA, Masashi OHTSUKA and Akifumi UENO

Toyohashi University of Technology Tempaku-cho, Toyohashi, Aichi 440,
\end{abstract}

(Received April 13, 1987)

\begin{abstract}
Control of a radial concentration of nickel metal particles in an alumina sphere was achieved by impregnating the sphere with a solution composed of nickel nitrate dissolved in ethylene glycol, ethyl silicate, and a small amount of nitric acid. The position of the nickel narrow band from the center of the sphere was well controlled merely by the impregnating time. The nickel loading in the catalyst was intentionally varied with the nickel concentration in the impregnating solution.

The external surface of the catalyst prepared was covered with a thin $\mathrm{SiO}_{2}$ film resulted from gelling of ethyl silicate over the alumina sphere. The micro-pores observed in the thin $\mathrm{SiO}_{2}$ films were sharply sized around $20 \AA$.

One of the features of this technique is the formation of macro-molecules consisting of $\mathrm{Si}-\mathrm{O}-\mathrm{Ni}$ $\mathrm{O}-\mathrm{Si}$ structure during the preparation of impregnating solution. When the alumina spheres were immersed, these macro-molecules adhere to the external surface of the spheres, followed by the elimination and migration of $\mathrm{Ni}$ ions into spheres to form a radial distribution of the fine metal particles.
\end{abstract}

担持金属触媒では, 触媒反応は金属粒子上で進行す る。したがって，触媒作用は金属粓子の物性により変化 する。金属粒子の物性は異種金属成分の添加，すなわ ち，合金化により容易に変化するが"，金属粒子そのむ のの粒子径を変えることによって屯制御できる2。乙の ような観点から，金属粒子の粒径を制御するととによ り，望ましい触媒作用を発現させようとする研究がおこ なわれている3゙。また，一方では，金属粒子の担体とし て，アルミナやシリカなどの耐熱性酸化物粉体が種々の 形状に成型されて用いられているが，担体中での金属粒 子の分布位置を制御しようという研究もおてなわれてい る。乙れは反応中に金属成分が飛散したり，反応ガス中 の不純物により金属成分が被毒されたりするととへの対 処を，主な目的としている。

ここでは，著者等が，触媒中の金属粒子の粒径を制御 する目的で検討中であるアルコキシド法をさらに発展さ せ，粒径之同時に金属粒子の分布位置まであ制御するこ とを試みた結果について述べる゙

\section{1. 含浸液の調整}

アルコキシド-含浸法とむ呼ぶべきての方法は，含浸
液中での金属イオンの固定化からはじまる。含浸方法の 手順については Table 1 亿示してあるが，含浸液は通

Table 1 Preparation procedures for $\mathrm{Ni} / \mathrm{SiO}_{2} / \mathrm{Al}_{2} \mathrm{O}_{3}$ catalyst.

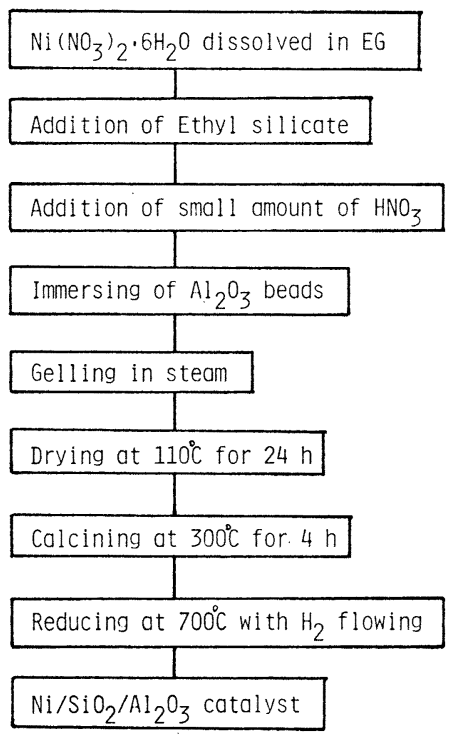


常, $150 \mathrm{ml}$ のエチレングリコール $(\mathrm{EG})$ に $9 \mathrm{~g}$ の硝酸二 ッケルを溶解し, これに $30 \mathrm{ml}$ のケイ酸エチル $(\mathrm{ES})$ と $3 \mathrm{ml}$ の硝酸を添加して調製する。この混合溶液を室温で 3 時間かくはんした後アルミナ球を洨漬するわけである が，かくはん後の溶液中には ( $\mathrm{Si}-\mathrm{O}-\mathrm{Ni}-\mathrm{O}-\mathrm{Si})$ という睤 造をもった高分子状の哭機物が生成しており ${ }^{5)}$, この棈 造中に Ni イオンが固定化されている。このような無機 高分子物質の生成がアルコキシドー令浸法の特徽である。

\section{2. 含浸手順}

Table 1 の手順にしたがい, 㨁徍 $3 \mathrm{~mm}$ のアルミナ球

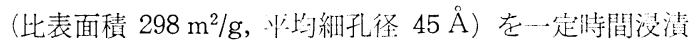
した後, 水蒸父中に放䠗しアルミナ球の表面でゲル化さ せる。これを $110^{\circ} \mathrm{C}$ で乾燥し， $300^{\circ} \mathrm{C}$ で 4 時間焼成後,

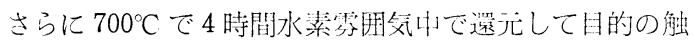
媒とした。

\section{3. ニッケルとケイ素の分布}

還元後の球状触媒をポリエステル系の樹脂に埋め込 み，樹脂を研磨することにより触媒球の正径㸫面を露出 させ，その断面上での $\mathrm{Ni}$ と $\mathrm{Si}$ の分布を EPMA によ
り測定した。その結果を触媒の杵面写真とともに Fig.

1 に示した。斨面写真中, 照い苴状の部尔が濃縮された ニッケル金属粒子であり, 球教状に分布していることが

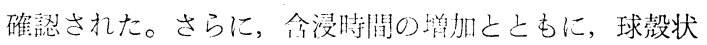
ニッケル金属粒子の分布位监がナルミナ球の中心部に移 動することも明らかになった。Fig. 2 に含浸時間と二 ッケル精子带の位狊との関係を示してある。一方，ケイ 絜の分布は含浸時間に関係なく, 常にアルミナ外表面に シャープな分有をし， $\mathrm{SiO}_{2}$ 溥膜として (平均厚さ約 30 ル) アルミナ担体の表䤃をコートしていることが確認で きた。

\section{4. 触媒中のニッケル担持量}

含浸液中のニッケル濃度が一定であれば，含浸時間に 上らず触媒中のニッケル担持星も一定であるこレが，け い光X線分析により判明した。つまり，弇浸侍間を長く してもニッケルの担持量は增加せず，ただ，ニッケルの 分布位置だけがアルミナ球の中心部に移動するだけであ る。触媒中のニッケル担持量老制御するためには含浸液 中のニッケル濃度を調節すればよい。含浸液中のニッケ

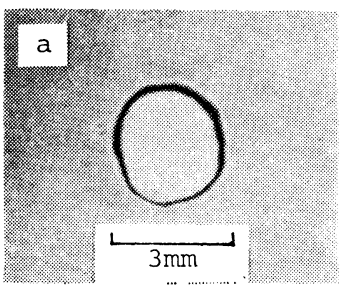

NI $50 \mathrm{cps}$

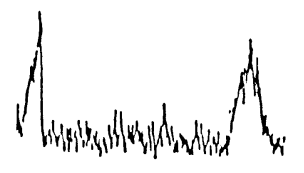

b

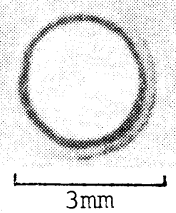

NI

$50 \mathrm{cps}$

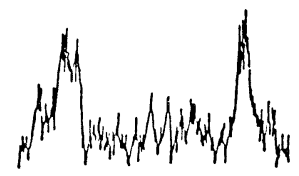

\section{C}

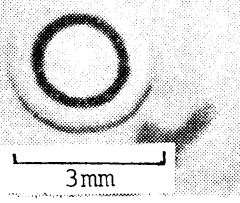

NI $50 \mathrm{cps}$

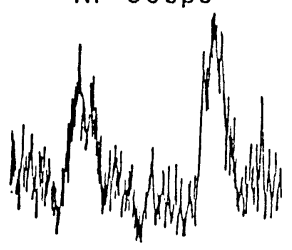

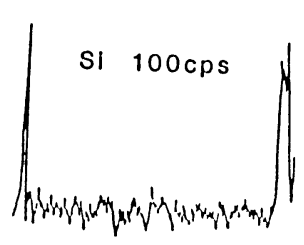
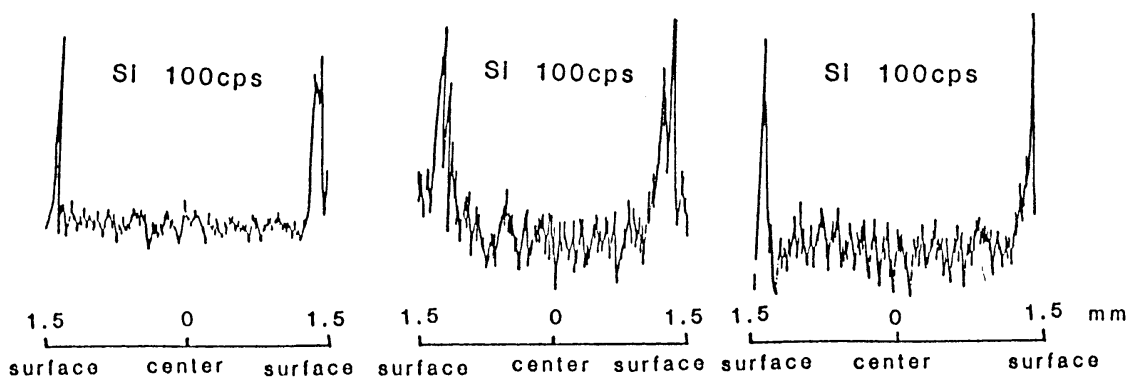

$1 \mathrm{~min}$

Fig. 1 SEM photographs and EPMA analyses of Si and Ni. 


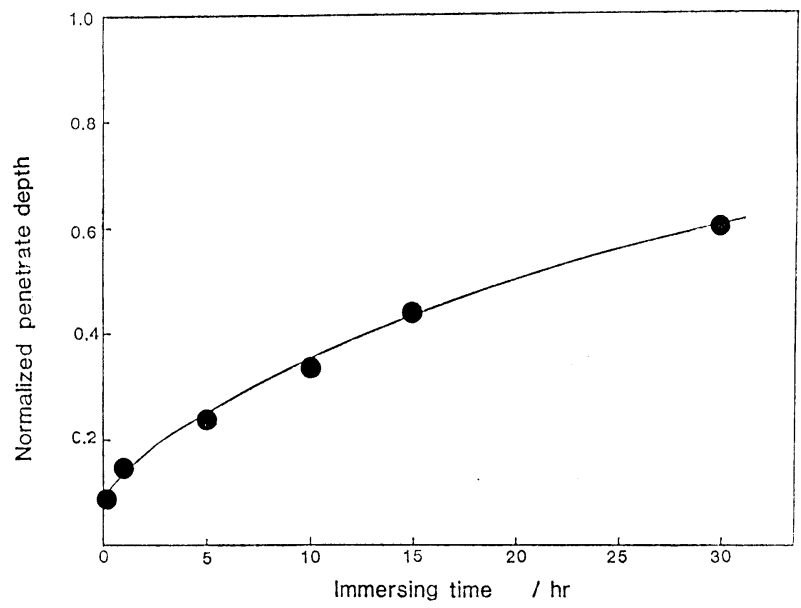

Fig. 2 Effect of immersing time on $\mathrm{Ni}$ band position in $\mathrm{Al}_{2} \mathrm{O}_{3}$ beads.

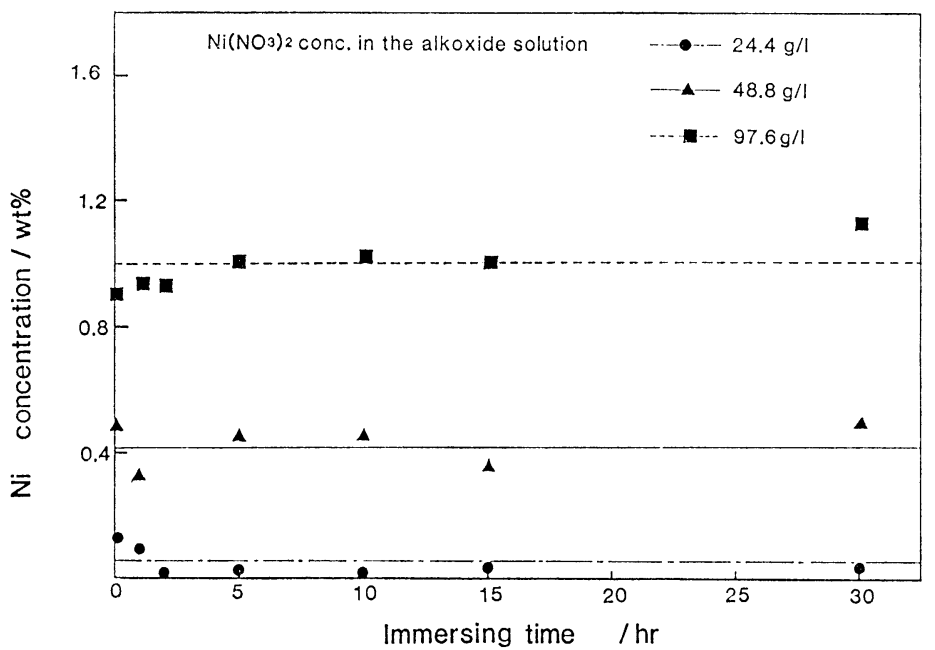

Fig. 3 Relationship between immersing time and $\mathrm{Ni}$ concentration in the catalysts.

ル濃度を変えた場合のニッケル担持量の変化の様子を

Fig. 3 亿示した。以上のことから, 触媒中のニッケル担 持量は含浸液中のニッケル濃度により, また, ニッケル 粒子の分布位置は含浸時間により，ほほ，自由に制御で きるととがわかった。ただし、ニッケル粒子带の幅は二 ッケル担持量の増加ととあに若干增大した。

\section{5. ニッケル金属粒子の粒径}

上記の触媒（ $\mathrm{Ni}$ 担持率 $=0.4 \mathrm{wt} \%)$ 中のニッケル金 属粒子の粒径を，透過型電子顕微鏡により測定した。そ の TEM 写真の一部を Fig. 4 にしめした。てれは含浸 時間が 1 分のものであり, 粒子径約 $80 \AA$ の Ni 金属粒 子が均一に高分散している様子をしめしている。Fig. 1 の断面写真ではニッケル金属のみが黒く帯状に存在して いるように見えたが，実際にはアルミナ中に高密度で存
在していることがわかった。含浸時閂の增加とともに二 ッケル带の位置が内部に移動するため, 球款带中での二 ッケル粒子の高密度化が進行し, ニッケルの粒子径が若 干增大する。(15 時間含浸で約 $135 \AA$ になる。)

触媒化学の分野では, 水素の化学吸着量を測定して金 属粒子の粒径を推測しているので6)，その方法をこの触 媒にも適用した。700 $\mathrm{C} て ゙$ 還元後の触媒では, 全ての $\mathrm{Ni}$ イオンが金属に還元されているととを飽和磁化率の測定 により確かめたあと，水菜吸着の測定を行った。結果を

Table 2 に示した。水素吸着法により求めた粒径は, TEM により求めたものとよく一致していた。てのこと は触媒中の二ッケル粒子のほとんど全てが水素吸着, 従 って, 触媒反応に関与できる状態にある, というととを 意味している。 
Table 2 Particle size of $\mathrm{Ni}$ in $\mathrm{Ni} / \mathrm{SiO}_{2} / \mathrm{Al}_{2} \mathrm{O}_{3}$ catalyst measured by $\mathrm{H}_{2}$ chemisorption and TEM.

\begin{tabular}{l|c|c|c|c|c}
\hline $\begin{array}{l}\text { Immersing } \\
\text { time }\end{array}$ & $\begin{array}{c}\text { Volume of } \mathrm{H}_{2} \\
\text { adsorbed } \\
(\mathrm{ml} / \mathrm{g} \mathrm{Cat.})\end{array}$ & $\begin{array}{c}\text { Surface area } \\
\text { of } \mathrm{Ni} \\
\left(\mathrm{m}^{2} / \mathrm{g} \mathrm{Ni}\right)\end{array}$ & $\begin{array}{c}\text { Dispersion } \\
\text { of Ni } \\
(\%)\end{array}$ & $\begin{array}{c}\text { Mean particle } \\
\text { size of Ni } \\
(\AA)\end{array}$ & $\begin{array}{c}\text { Mean particle } \\
\text { size of Ni by } \\
\mathrm{TEM} \\
(\AA)\end{array}$ \\
\hline $1 \mathrm{~min}$ & 0.095 & 94.4 & 13.5 & 70 & 80 \\
$2 \mathrm{~h}$ & 0.084 & 76.8 & 11.0 & 90 & 110 \\
$15 \mathrm{~h}$ & 0.059 & 61.2 & 8.8 & 110 & 135 \\
\hline
\end{tabular}

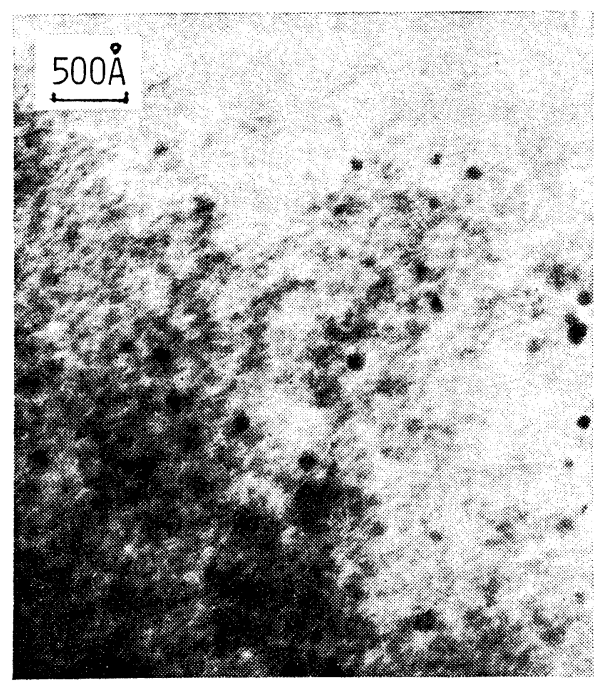

Fig. 4 TEM photograph of $\mathrm{Ni}$ particles in the catalyst.

\section{6. 含浸液中の硝酸の影響}

含浸液の調製時に添加する硝酸の働きは何であろう か。その詳細はあとで 9 節で述べる。ことでは硝酸の添 加量とニッケル金属粒子の分布位置および担持量との関 係について検討する。Fig. 5 および Fig. 6 には, 含浸

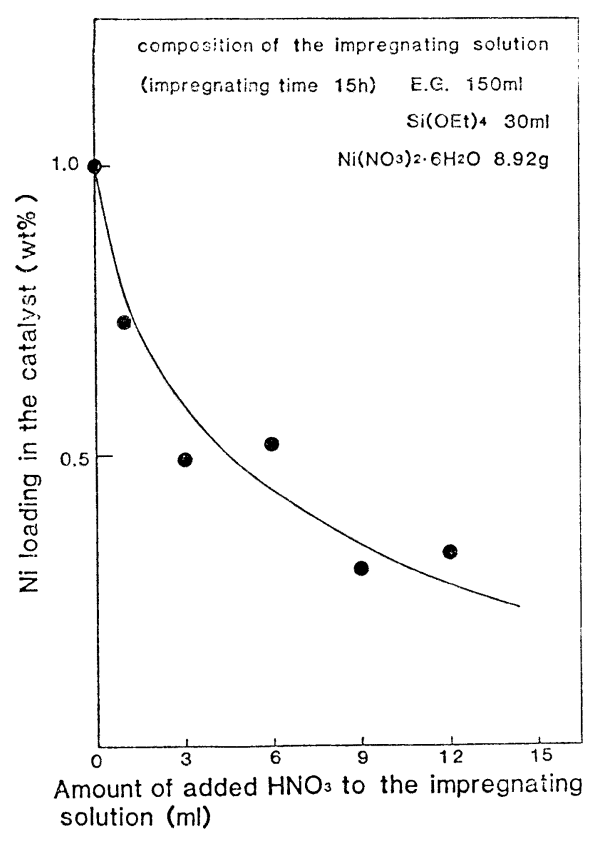

Fig. 6 Effects of $\mathrm{HNO}_{3}$ upon the $\mathrm{Ni}$ loading in the catalyst.

時間を 15 時間に固定した場合の硝酸添加量とニッケル の分布位置および担持量との相関性を示した。これよ

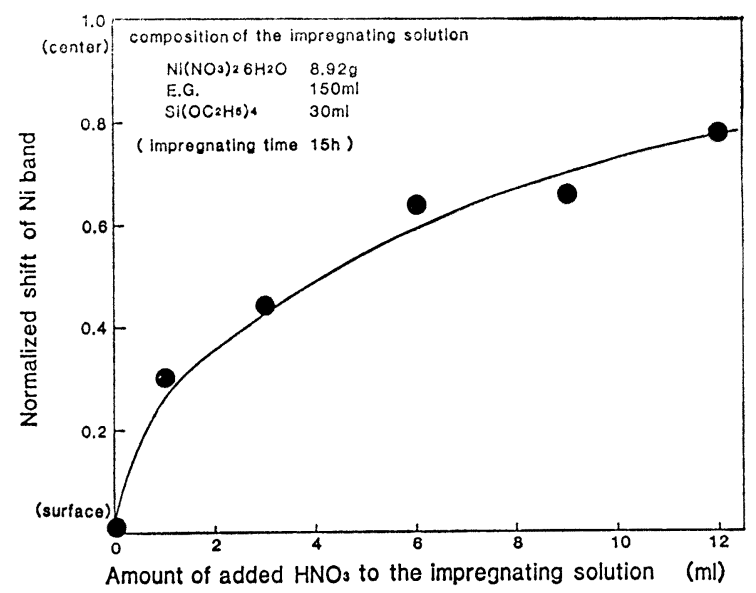

Fig. 5 Effects of $\mathrm{HNO}_{3}$ upon the position of $\mathrm{Ni}$ band. 
り，硝酸量を増すと同じ含浸時間であってもニッケルの 分布位置はアルミナ球の内部に移動すること, および, ニッケルの担持量は硝酸の添加量の増加とともに減少す ることが判明した。したがって，含浸時間や含浸液中の ニッケル濃度だけでなく, 含浸液に添加する硝酸の量に よってもニッケルの分布位置や担持量を制御することが 可能である。

\section{7. シリカ薄膜の性状}

還元後の触媒の比表面積は $201 \mathrm{~m}^{2} / \mathrm{g}$ であり, 未含浸 のアルミナ担体 $\left(298 \mathrm{~m}^{2} / \mathrm{g}\right)$ に比べ若干減少した。また, $\mathrm{N}_{2}$ を用いたガス珐入法によりアルミナ担体および還元 後の触媒の細孔分布を測定したところ，Fig. 7 に示す ような結果を得た。すなわち, アルミナ担体，還元後の 触媒ともにシャープな細孔分布を有し, 平均細孔径はそ れぞれ，45 および $20 \AA$ だあった。したがって，還元 後の触媒の外表面はシリカ薄膜でコートされており, そ のシリカ薄膜には約 $20 \AA$ の細孔が均一に分布してい るあのと考えられる。触媒断面を拡大した宁真とこの EPMA 測定の結果を Fig. 8 に示した。乙れより, シリ 力薄膜の見掛上の平均膜厚は約 $30 \mu$ と推定された。

アルミナ担体の細孔容積は $0.33 \mathrm{ml} / \mathrm{g}$ であり, 還元後 の触媒のそれが $0.35 \mathrm{ml} / \mathrm{g}$ とあまり変わらないことを考 慮すると, シリカ薄膜の生成はアルミナ担体の細孔では
なく, 担体の外表面で生じているあのと思われる。

\section{8. 硫化水素およびチオフェンの吸着}

アルミナ担体を硫化水素 $\left(0^{\circ} \mathrm{C}\right)$ およびチオフェン（室 温）雲围気中に放置したのち，EPMA でイオウの分布 を測定したところ，担体内部まで一様に分布しているて とがわかった。還元後の触媒についても同様な実験を行 ったところ, Fig. 9 に示すように，硫化水素の場合には イオウはニッケル上に濃縮されたが, チオフェンの場合 には触媒球内部に浸入することができず，触媒の外表面 部にのみ存在していることが判明した。このことは, ガ ス圧入法では $20 \AA$ 亡推定されたシリカ薄膜上の細孔 が，実際にはむっと小さいものであるということを意味 している。ガス圧入法では細孔を円筒形であると仮定し て, 細孔容積から算出しているためであり, 実際には, いわゆるインクボトル型の細孔をしているのであろう。 いずれにしてむ，還元後の触媒の外表面をコートしてい るシリカ薄膜にはチオフェン（分子径約 $4.0 \AA$ ) をも通 さない小さな細孔が均一に分布していると結論できる。

\section{9. 分布位置制御の機構}

エチレングリコール (EG) に硝酸ニッケルを溶解さ せ,さらに, ケイ酸エチル (ES) を混合すると以下に示 すような反応が進行し, Si-O-Ni-O-Si という構造を持 った高分子が生成する5)。

$$
\begin{aligned}
& \begin{array}{l}
\mathrm{CH}_{2}-\mathrm{OH} \\
\stackrel{\mathrm{C}}{\mathrm{C}} \mathrm{H}_{2}-\mathrm{OH}
\end{array}+\mathrm{Ni}\left(\mathrm{NO}_{3}\right)_{2} \rightleftarrows \mathrm{Ni} \backslash \stackrel{\mathrm{O}-\mathrm{CH}_{2}}{\mathrm{CH}_{2}}+2 \mathrm{H}^{+}+2 \mathrm{NO}_{3}^{-}
\end{aligned}
$$

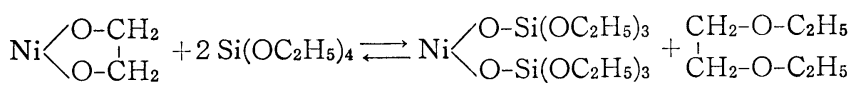

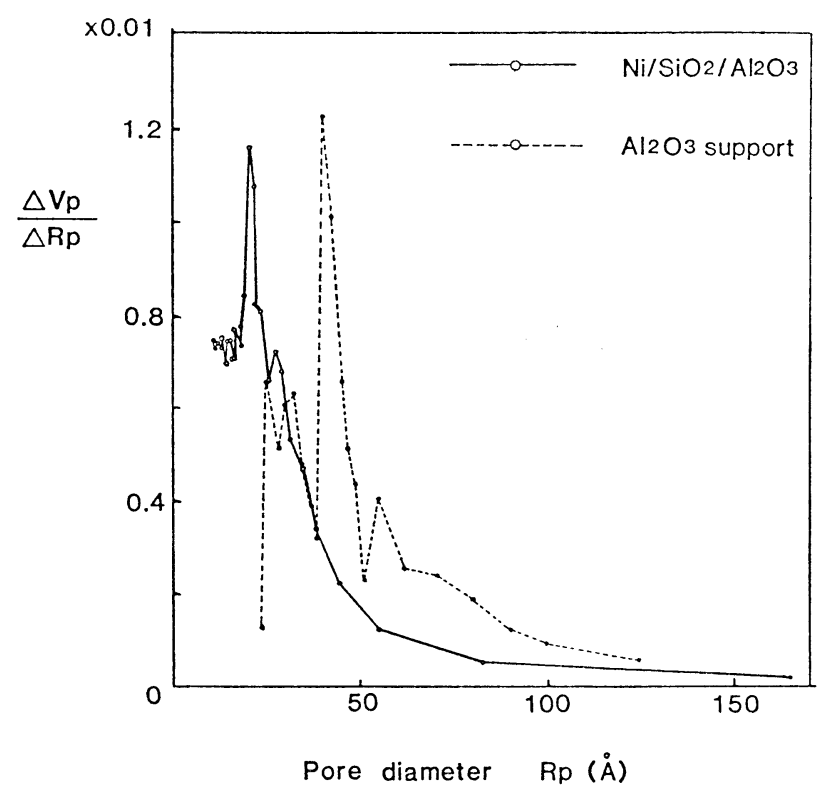

Fig. 7 Pore size distributions of bare $\mathrm{Al}_{2} \mathrm{O}_{3}$ and $\mathrm{Ni} / \mathrm{SiO}_{2} / \mathrm{Al}_{2} \mathrm{O}_{3}$. 

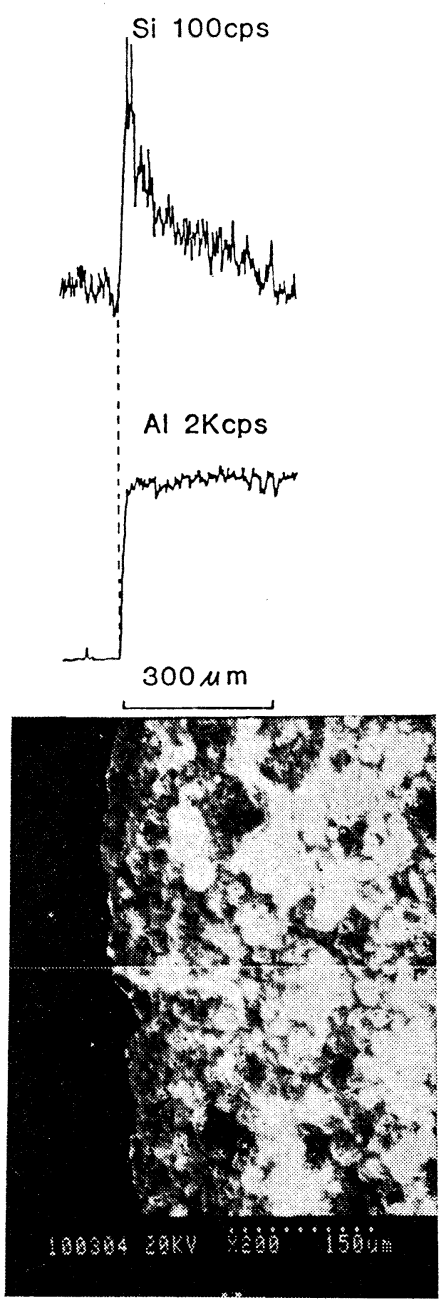

Fig. 8 XMA profile of $\mathrm{Si}$ and $\mathrm{Al}$ in the catalyst.

この様な高分子構造を有する溶液中にアルミナ球を浸漬 すると, 球外表面に吸着した $\mathrm{Si}-\mathrm{O}-\mathrm{Ni}-\mathrm{O}-\mathrm{Si}$ 構造は分 解し, $\mathrm{Ni}$ イオンは $\mathrm{H}^{+}$と競争吸着しながら球の内部に 原子状で拡散し, 球款状に二ッケル粒子帯を形成する。 $\mathrm{H}^{+}$との競争吸着であるため, 含浸時間を長くしたり硝 酸を添加したりすると， Ni イオンはより内部に追いや られることになる。一方, 球表面は $\mathrm{Si}-\mathrm{O}-\mathrm{Si}$ ネットワー クで覆われ, 焼成, 還元後にはシリカ薄膜を生成する。 したがって，アルミナ球内部に拡散する Ni イオンの量 は最初に吸着した $\mathrm{Si}-\mathrm{O}-\mathrm{Ni}$ の量, 即ち含浸液中の $\mathrm{Ni}$ イオンの濃度により決定される。また, 含浸中に球内部 に昖散する $\mathrm{Ni}$ イオンは原子状であり, 球款状に一様に 分布するため, 還元後に生成するニッケル金属粒子の粒 径屯均一になると考えられる。Fig. 10 に以上の様子を モデル化してしめした。
ただし、Si-O-Ni-O-Si 構造が, なぜアルミナ球に吸 着したときに分解するのかについてはわからない。

\section{0. アルミナの等電位点}

含浸液中には $\mathrm{Si}-\mathrm{O}-\mathrm{Ni}-\mathrm{O}-\mathrm{Si}$ 構造に固定されない $\mathrm{Ni}$ イオンも存在するはずである。とれらの自由な $\mathrm{Ni}$ イオ ンはアルミナ中に担持されないのだろうか。とのととを 説明するためにはアルミナの等電位点について考慮する 必要がある。アルミナ粉末を溶液中に分散するとその表 面には電気二重層が生成するが, その電荷は溶液の $\mathrm{pH}$ により著しく左右される。アルミナの等電位点は約 9.0 であり7)，それより酸性側では電気二重層は十に荷電さ れる。本実験で用いている含浸液の $\mathrm{pH}$ は通常 1 以下で あり,したがって含浸液中のアルミナ球表面は十に荷電 された電気二重層で覆われている。そのため, 自由な $\mathrm{Ni}$ イオンのように+の電荷を持ったイオンは静電的な 反発力により，アルミナ表面にちかよることができな い。Si-O-Ni-O-Si のように+の荷電を有しないものの みがアルミナ表面に近づき吸着できるととになる。

\section{1. アルミナ担体の細孔径}

アルミナ担体をケイ酸エチルに含浸すると,ケイ素は アルミナ球の内部にまで一様に分布する。乙れはケイ酸 エチルだけでは重合せずモノマーとして存在するため, その分子径がアルミナ表面の細孔径よりあ小さく，した がって, アルミナ球の内部にまで拡散するととを意味し ている。このように考えると, Si-O-Ni-O-Si 構造を有 する高行子物質のサイズとアルミナの細孔径との間には 何らかの関係が存在すると思われる。そこで, 細孔径が 約 $100 \AA$ のアルミナ球を用いて同様な含浸操作を試み た。その結果, 乙の場合には, ニッケルもケイ素もアル ミナ球の内部に進入するととが判明した。このととよ り, 本条件下では, Si-O-Ni-O-Si 構造を有する高分子 のサイズは $45 \AA$ より大きく, $100 \AA$ よりは小さいあの と結論される。含浸液の調製条件を変えるととにより, この高分子物質のサイズを制御できればアルミナ担体の 細孔径によらず，上記のような特徵をあった触媒が調製 できるであろう。

\section{2. 触媒以外への応用}

触媒担体の製造に用いたものと同じアルミナ粉末を直 径 $20 \mathrm{~mm}$, 厚さ $2 \mathrm{~mm}$ のディスク状に成型し, 上述の含 浸液に 15 時間浸漬した。その後, 同様な方法で燒成, 還元を行なった。てのようにして調製したディスクの断 面写真とその EPMA 分析の結果を Fig. 11 に示した。 期待どうりに，ディスクの表面から一定の位置にニッケ ル金属微粒子が板状に分布し，かつ，ディスクの外表面 はシリカ薄膜で覆われていた。シリカ薄膜上の細孔径が 非常に微細であるととから, 内部の金属微精子の酸化を 
$\mathrm{H}_{2} \mathrm{~S}$ adsorption<smiles>CCOC(=O)OCCO</smiles>
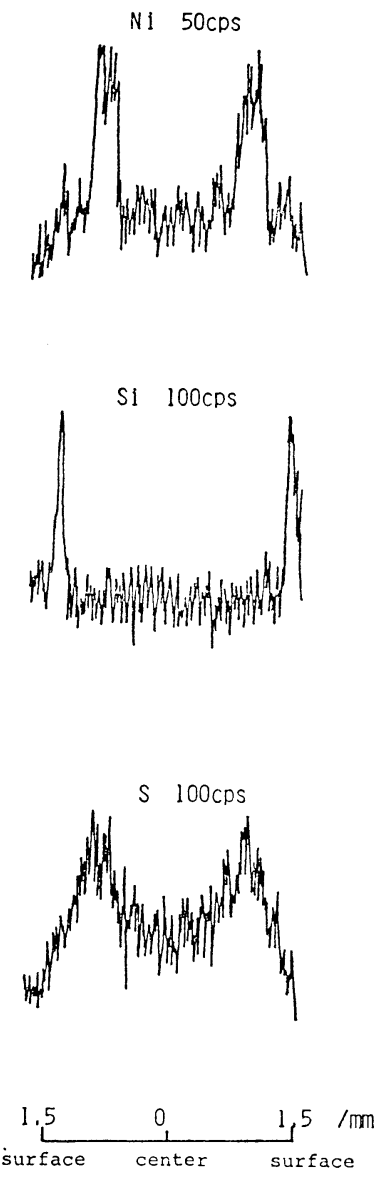

Fig. $9 \mathrm{H}_{2} \mathrm{~S}$ and $\mathrm{C}_{4} \mathrm{H}_{4} \mathrm{~S}$ adsorption on $\mathrm{Ni} / \mathrm{SiO}_{2} / \mathrm{Al}_{2} \mathrm{O}_{3}$ catalyst.

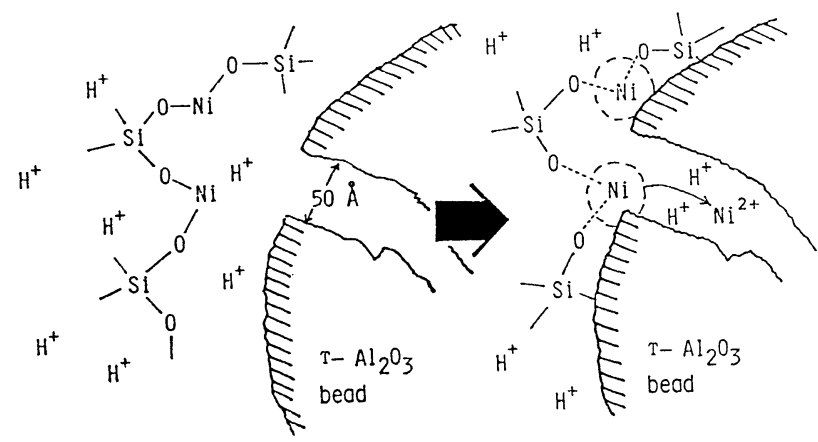

Fig. 10 Model for $\mathrm{Ni}$ band formation. 

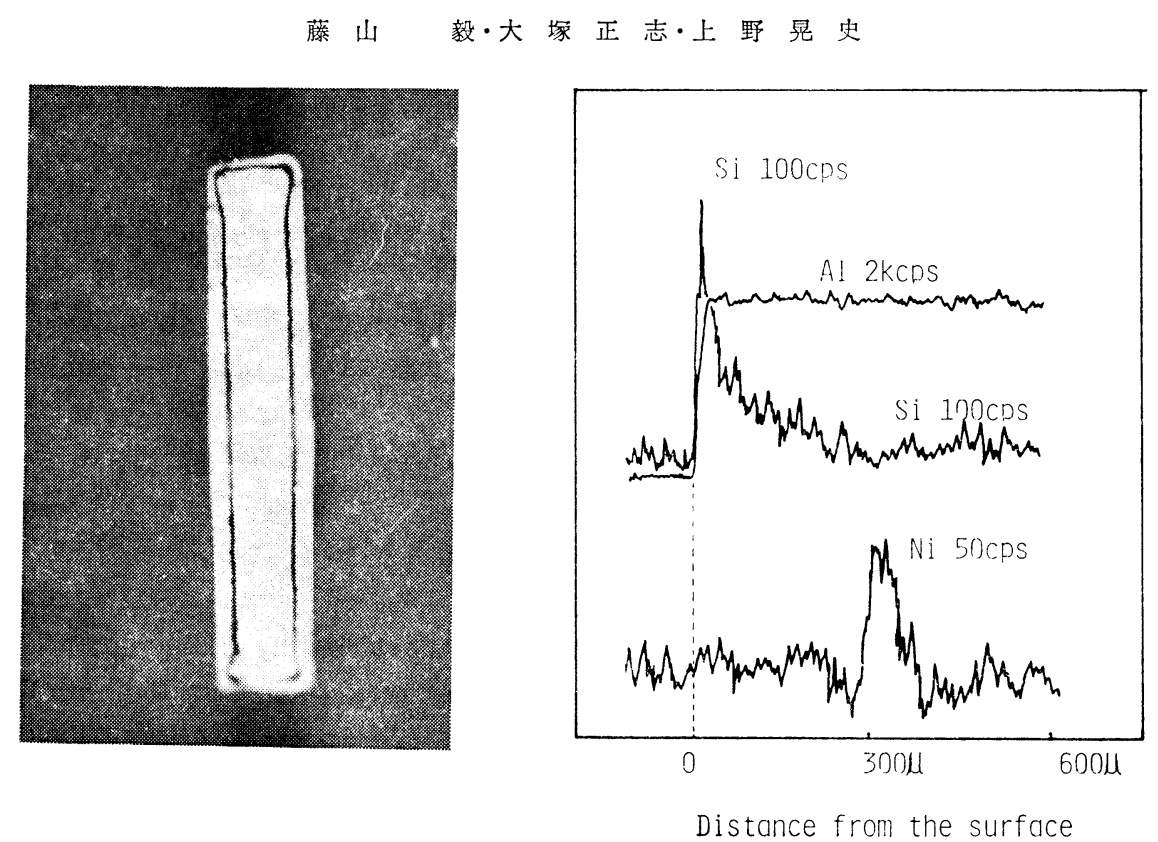

Fig. 11 SEM photograph of disc composed $\mathrm{Ni}, \mathrm{Si}$ and $\mathrm{Al}$.

抑える効果が期待される。とのような構造的特徽は, 触 媒だけでなく他の機能性材料に応用できるであろう。

ニッケルだけではなく，コバルトなどの金属にも適用 できることを確かめてあるので8，今後は合金微粒子の 分布位置制御を目指し，ハードな磁気ディスクへの応用 を究極の目的としている。

\section{文献}

1) H. C. de Jongste, V. Ponec and F. G. Gault: J. Catal. 64, 389 (1980); M. J. P. Bootman, H. C. de Jongste and V. Ponec: J. Catal. 68, 389 (1980); Xuan-zhen Jiang, S. A. Stevenson and J. A. Dumesic: J. Catal. 91, 11 (1985); A. G. Shastri and J. Schwank: J. Catal. 95, 271 (1985); G'del Angel, B. Coq and F. Figueras: J. Catal. 95, 167 (1985); G. Sankar, S. Vasdevan and C. N. Rao: J. Phys. Chem. 90, 5325 (1986).

2) M. Boudart: J. Catal. 4, 704 (1965); J. L. Carter, J.A. Cusumano and J.H. Sinfelt: J. Phys. Chem. 70, 2257 (1966); P. H. OteroScipper, W. A Wachter, J. B. Butt, R. L. Burwell Jr. and J.B. Cohen: J. Catal. 53, 414 (1978); M. Nakamura, M. Yamada and A.
Amano: J. Catal. 39, 125 (1975); H. Arai : Hyoumen (Surface) 17, 675, 746 (1979); A. Ueno: Hyoumen (Surface) 22, 18 (1984).

3) R. W. Maatman and C. D. Prater: Ind. Eng. Chem. 49, 253 (1957), 51, 913 (1959); J. C. Summers, and L. L. Hegedus: J. Catal. 51, 185 (1978); H. C. Chen and R. B. Anderson: J. Catal. 43, 200 (1976); M. Komiyama, R.P. Merrill and H.F. Harnsberger: J. Catal. 63, 65 (1980).

4) T. Fujiyama, H. Tsuiki and A. Ueno: Chem. Lett. 373 (1986); T. Fujiyama, M. Ohtsuka, H. Tsuiki and A. Ueno: J. Catal. (in press).

5) A. Ueno, H. Suzuki and Y. Kotera: JCS, Faraday Trans. 1, 79, 127 (1983); K. Tohji, Y. Udagawa, S. Tanabe and A. Ueno: J. Am. Chem. Soc. 106, 612 (1984).

6) H. Gruber : J. Phys. Chem. 66, 48 (1962); W. K. Hall and G. R. Wilson: J. Catal. 17, 190 (1970); D. G. Mustard and C. H. Bartholomew : J. Catal. 67, 186 (1981).

7）“触媒調製化学” 尾崎 萃編 (講談社, 1980) p. 40.

8) M. Ohtsuka, T. Fujiyama, H. Tsuiki and A. Ueno: Bull. Chem. Soc. Jpn. (to be submitted). 